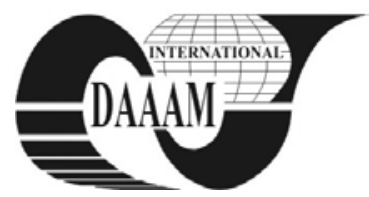

Annals of DAAAM for 2011 \& Proceedings of the 22nd International DAAAM Symposium, Volume 22, No. 1, ISSN 1726-9679 ISBN 978-3-901509-83-4, Editor B. Katalinic, Published by DAAAM International, Vienna, Austria, EU, 2011 Make Harmony between Technology and Nature, and Your Mind will Fly Free as a Bird Annals \& Proceedings of DAAAM International 2011

\title{
TRANSFORMING LEARNING FOR LIFELONG LEARNING IN THE KNOWLEDGE ECONOMY
}

\author{
POPESCU, A[lina] - I[rina]
}

\begin{abstract}
The paper is based on the research of the ways in which education and training are shaped by the emergence of the knowledge economy. The premise is that the educational system is a catalyst for the knowledge economy, but at the same time, it needs to adapt to the requirements of the new economic model. Therefore, this paper focuses on the learning process, by attempting to capture how it is influenced and transformed by the requirements of the knowledge economy, elaborate on the features of the new learning model called 'lifelong learning', and emphasize how information and communication technologies shape the educational activities at the beginning of the $21^{\text {st }}$ century.
\end{abstract}

Key words: education, lifelong learning, knowledge economy

\section{INTRODUCTION}

The emergence of the knowledge economy (KE) in the era of globalisation raises pressures for the education and training systems. At the same time, the rapid development of technology has brought transformation in the learning process. A new learning model has emerged, its importance being emphasized now more the ever before. Following an extensive literature review, the paper discusses the influence of the knowledge economy on education, and attempts to identify the transformations incurred by the learning process according to the requirements of the knowledge economy.

\section{KNOWLEDGE ECONOMY'S IMPLICATIONS FOR EDUCATION AND TRAINING}

The role of knowledge as an essential force for development was highly acknowledged by scholars and international organisations (Keep and Mayhew, 1999, World Bank, 2007). Among the attempts to structure the knowledge economy the one proposed by the World Bank (2007) clarifies best the relationship between the knowledge economy and the educational system (including research and innovation activities). The implications of the knowledge economy for education were also researched by Conceicao et al (1998), Goddard and Chatterton (1999), Robertson (2005).

The KE is transforming the demands of the labour market in economies throughout the world. Technological change has brought about the demand for high-skilled workers, particularly highly-skilled in ICT, and a decrease in the demand for lowskilled workers (OECD, 2001a). Skills, competences and qualifications acknowledge and measure the outcomes of education in the knowledge economy. Competences acquisition and improvement represent not only a requirement for those with high qualifications working in hi-technology industries, but also a necessity for everybody, especially for underqualified workers that are the most vulnerable category to the changes in the labour markets. As such, education and training systems need to re-organize to evaluate the learning processes based on their outcomes: skills, competences and qualifications. Basic competences for the KE - meaning competences to be

\begin{tabular}{|ll|}
\hline Competency area & Content \\
\hline Cognitive & $\begin{array}{l}\text { Language, communication, logistical and } \\
\text { mathematical thought }\end{array}$ \\
\hline Problem solving & $\begin{array}{l}\text { Observing, analyzing, identifying the parts of a } \\
\text { problem, suggesting creative solutions, critical } \\
\text { thinking, planning and project management skills } \\
\text { Adapting knowledge to new contexts }\end{array}$ \\
\hline $\begin{array}{l}\text { Self-learning and } \\
\text { self-knowledge }\end{array}$ & $\begin{array}{l}\text { Being informed and motivated to learn, concern with } \\
\text { one's own development, knowledge of one's } \\
\text { capacities, ability to transfer knowledge from one } \\
\text { context to another }\end{array}$ \\
\hline Social & $\begin{array}{l}\text { Working in a team, negotiating and creating } \\
\text { constructive arguments, interacting, getting others to } \\
\text { understand one's point of view, self-confidence, } \\
\text { seeking and maintaining networks of social contacts }\end{array}$ \\
\hline $\begin{array}{l}\text { Motivation for } \\
\text { work }\end{array}$ & Initiative, responsibility, commitment, and interest \\
\hline
\end{tabular}

Tab. 1. New Competences for the Knowledge Economy

acquired by everybody as mandatory for KE (Table 1 summarized by Vargas Zuñiga (2005), demonstrate the challenges the educational systems face.

Changes brought by the knowledge economy are so rapid that make knowledge easily obsolete. As such people need to continuously acquire new knowledge throughout their lifetime. Therefore, educating and training individuals for KE requires $a$ new model of education and training, called lifelong learning. The concept is not new; its emergence can be traced back to the discussions led by UNESCO and OECD in 1960s and 1970s (Popescu, 2011). Previous researches in this area discuss the evolution of the concept in EU policy (Brine, 2006), and discuss or compare the implementation of lifelong learning strategies in different countries (Hillier, 2000; Popescu, 2011).

\section{THE TRANSFORMATION OF LEARNING IN THE LIFELONG LEARNING MODEL}

The results of the research conducted on how KE requirements transform the process of learning are interpreted below, based on the core aspects of education.

The lifelong dimension of the learning process is a characteristic that defines learning in the KE. The traditional approach of studying for a finite period of time to complete education before moving to the labour market is increasingly replaced by the continuous learning throughout the entire lifecycle of the individual. This represents a requirement of the $\mathrm{KE}$, since knowledge is developing at a faster pace, becoming easily obsolete and requiring individuals to continuously update and upgrade their knowledge, skills and competences.

Beside formal education and training, the lifelong learning educational model recognizes the importance of non-formal and informal education. At present, learning that occurs outside the formal learning system is not well understood, made visible or, probably as a consequence, appropriately valued. Most research has focused on learning outcomes from formal education and training, instead of embracing all types of learning outcomes, allowing the visibility and portability of such outcomes in the lifelong learning system, in the labour market or in the community. 
In the knowledge economy, the individual is the owner of knowledge. In addition, individuals are expected to actively seek to acquire and develop knowledge and competences. Therefore, the educational system shall place the learner and his / her needs in the centre of the learning process, which needs to register a shift from teaching to learning practices. A learnercentred environment allows new knowledge to become available for use in new situations, enhancing the transfer of knowledge.

A requirement of the knowledge economy is that the learning system must reach larger segments of the population, including people with diverse learning needs. E-learning and mobile learning enhanced by ICT developments are means to target even the most remote categories of learners.

In addition, tertiary education institutions have to reorganize to accommodate the learning and training needs of a more diverse clientele (adult students, working students, stayat-home students, part-time students, travelling students, evening students, weekend students etc.). New patterns of the demand for learning emerge whereby students attend several programs or institutions in parallel or sequentially. The development of the ECTS is of particular importance for the lifelong learning model, where learners should be able to enter and exit the learning system according to their learning needs.

In the knowledge economy, learning needs to become competence-driven. Instead of memorizing facts and data that easily becomes obsolete, the learning process has to allow the development of the methodological knowledge and analytical skills - skills needed for learning to think and to analyze information independently. Primacy is given to learning to learn, learning to transform information into knowledge and translate new knowledge into application with the use of competences that employers value in the knowledge economy: analytical skills, oral and written communications, teamwork, peer teaching, creativity, envisioning skills, self-improvement, ability to adjust to change and others alike.

Knowledge-rich learning favours teaching fewer subjects areas in depth, rather than covering more subjects in less depth. According to Martin et al (2000), this kind of learning provides learners with a variety of strategies and tools for retrieving and applying or transferring knowledge to new situations, being more competence-driven than factual knowledge memorization.

Research shows that the roles and responsibilities of teachers, trainers and other learning facilitators are also challenged by the transformation of learning. In the traditional model of learning, teachers tell learners what they need to know. In the new learning model, teachers work as learning facilitators, enable learners to access knowledge and develop their conceptual understanding. Thus teachers need to develop new pedagogical approaches, new skills and competences among which ICT, foreign languages, multi-cultural competences, and new values like tolerance and democracy are of outmost importance. In the lifelong learning context, the learning facilitator is a lifelong learner.

The process of learning needs to be community connected as the circumstances in which learning takes place have an important effect on the way people learn. The objectives of learning include active citizenship, personal fulfilment and social inclusion, equal opportunity, as well as employmentrelated aspects. Implicit learning is linked to successful participation in social interaction (OECD, 2001b). Moreover, working on real-life problems or issues that are relevant to learners increases interest and motivation and promoted knowledge transfer (Cibulka et al, 2000).

The usage of ICT in learning has the potential to improve the quality of learning, expand access to learning opportunities, and increase the efficiency of administrative processes. These technologies can support changes in pedagogy and teacher training, deepening and extending planned changes. Also, ICT changes the role of teacher in the lifelong learning model. The availability of online curricular material suggests that the teacher's role is no longer to provide content, but rather to work with learners to develop new territory. The Internet offers immense potential as enabler for interactive electronic learning infrastructure in the creation and distribution of knowledge and intelligence networks.

\section{CONCLUSION}

The knowledge economy shapes and transforms the learning process and its components: the contexts (formal, nonformal and informal), the roles of the learner and the teacher, the outcomes of learning that shall be measured in terms of competences, skills and qualifications, the goals of learning (personal development, social inclusion, active citizenship, employability and competitiveness), new forms of pedagogy emerged due to the usage of ICT in education aiming to make learning more appealing and accessible to all learners in the KE. Thus, the research question - how learning is transformed in the $\mathrm{KE} \mathrm{-} \mathrm{is} \mathrm{addressed;} \mathrm{further} \mathrm{research} \mathrm{is} \mathrm{conducted} \mathrm{in} \mathrm{the}$ field of educational technologies employed in e-learning and mobile learning.

\section{ACKNOWLEDGEMENTS}

This work was co-financed from the European Social Fund through Sectoral Operational Programme Human Resources Development 2007-2013, project number POSDRU/1.5/S/ 59184 „Performance and excellence in postdoctoral research in Romanian economics science domain”.

\section{REFERENCES}

Brine, J. (2006). Lifelong learning and the knowledge economy, British Educational Research Journal, vol.32, issue 5, pp. 649-665, Routledge, ISSN: 0141-1926

Cibulka, J.; Coursey, S.; Nakayama, M.; Price, J. \& Stewart, S. (2000). Schools as Learning Organizations, Maryland

Conceicao, P; Heitor, M.V.; Oliveira, P.M. (1998). Expectations for the university in the knowledge-based economy, Technological Forecasting and Social Change, vol. 58, issue 3, pp: 203-214, Elsevier, ISSN: 0040-1625

European Commission (2001): Making a European Area of Lifelong Learning a Reality, Brussels

Goddard, J.B.; Chatterton, P. (1999). Regional Development Agencies and the knowledge economy, EPC-Government and Policy, vol. 17, issue 6, pp: 685-699, ISSN 0263-774X

Hillier, Y. (2000). Lifelong learning in the workplace: A comparison of France and the UK, Higher Education and its Communities, pp. 148-163

Keep, E.; Mayhew, K. (1999). The assessment: Knowledge, skills, and competitiveness, Oxford Review of Economic Policy, vol. 15, issue: 1, pp. 1-15, published: SPR, Oxford.

Martin, M.; Mullis, I.; Gonzalez, E.; Gregory, K.; Smith, T et al. (2000). Findings from IEA's Repeat of the Third International Mathematics and Science Study, Boston

OECD (2001a): Science, Technology, and Industry Scoreboard: Towards a Knowledge-Based Economy, Paris

OECD (2001b). Preliminary Synthesis of the Third High Level Forum on Learning and Sciences and Brain Research, OECD -CERI

Popescu, A.I. (2011). Steps for the Implementation of a Lifelong Learning System in Romania, Proceedings, Bucharest

Robertson, S.L. (2005). Re-imagining and rescripting the future of education, Comparative Education, vol. 41, issue 2, pp: 151-170, Routledge, ISSN: 0305-0068

Vargas Zuñiga, F. (2005) Key Competencies and Lifelong Learning. in Fernando Vargas Zuñiga, ed., Key Competencies and Lifelong Learning (81-118). Montevideo

World Bank (2007), Building Knowledge Economies: Advanced Strategies for Development, Washington DC 